\title{
PROGRAM SERAMBI ISLAMI EDISI JUM'AT \\ PADA SESI TELETILAWAH \\ (Upaya TVRI untuk Meningkatkan Pengetahuan \\ Membaca Alquran Secara Tartil bagi Pemirsa)
}

\author{
Wulan Furrie \\ Manajemen Komunikasi \\ Fakultas Ilmu Sosial dan Manajemen Institut STIAMI \\ Email : wulanlenggana77@gmail.com
}

\begin{abstract}
Quran is "the way of life" for Muslims. Reading Quran with tarteel is a must (Fardhu Ain). Therefore, TVRI as a public television that has a vision of educating the life of the nation contributed to invite audiences to improve their ability to read Quran with tarteel. This study aimed to determine what efforts made by TVRI to improve audiences' knowledge in reading Quran with tarteel. Qualitative research method used in this study with in-depth interview. Informant in this study was a producer who has ideas to create programs TELETILAWAH Serambi Islami on Friday edition. The analysis used Theories of influences on Mass Media Content introduced by Pamela J Shoemaker and Stephen D. Reese. The results of this study found a large number of audiences' attention to these programs and increased their awareness to read the Quran with tarteel.
\end{abstract}

Keywords: TVRI, Reading Qur'an with tarteel, Mass Media

\begin{abstract}
Abstrak
Alquran adalah "the way of life " bagi umat Islam. Membacanya secara tartil sesuai kaidah-kaidah yang belaku, hukumnya wajib ( Fardhu Ain ). TVRI sebagai Televisi publik yang mempunyai visi mencerdaskan kehidupan bangsa, berkontribusi untuk mengajak pemirsa meningkatkan kemampuan membaca Alquran secara tartil. Penelitian ini bertujuan mengetahui upaya yang dilakukan TVRI untuk meningkatkan pengetahuan pemirsa dalam membaca Alquran secara tartil. Metode penelitian kualitatif digunakan dalam penelitaian ini dengan teknik wawancara mendalam (indepth Interview). Informan dalam penelitian ini adalah Produser yang memiliki ide atau gagasan untuk membuat program TELETILAWAH Serambi Islami, edisi Jum'at. Analisis yang digunakan adalah Teori Hirarki Pengaruh Isi Media (Theories of influences on Mass Media Content) yang diperkenalkan oleh Pamela J. Shoemaker dan Stephen D. Reese. Hasil penelitian meunjukkan atensi pemirsa yang besar terhadap tayangan ini dan meningkatnya kesadaran membaca Alquran secara tartil.
\end{abstract}

Keywords : TVRI, Membaca Alquran, Tartil, Media Massa

\section{PENDAHULUAN}

Televisi sebagai kebudayaan dari audio visual merupakan medium paling berpengaruh dalam membentuk sikap dan kepribadian masyarakat secara luas. Televisi juga memiliki pengaruh yang sangat besar terhadap perkembangan 
masyarakat Indonesia. TVRI telah menjadi TV publik dimana program acaranya berorientasi pada pendidikan, kebudayaan dan kebangsaan, termasuk di dalamnya program-program dakwah Islam yang dikemas dalam program religi sebagai pemenuhan kebutuhan spiritual.

Secara terminologis dakwah Islam telah banyak didefinisikan oleh para ahli. Sayyid Qutb memberi batasan dengan "mengajak" atau "menyeru" kepada orang lain masuk kedalam sabil Allah SWT bukan untuk mengikuti da'i atau sekelompok orang. Ahmad Ghusuli menjelaskan bahwa dakwah merupakan pekerjaan atau ucapan untuk memengaruhi manusia supaya mengikuti islam. Abdul al Badi Shadar membagi dakwah menjadi dua tataran yaitu dakwah fardiyah dan dakwah ummah. Sementara itu, Abu Zahroh menyatakan bahwa dakwah itu dapat dibagi menjadi dua hal; pelaksanaan dakwah perseorangan dan organisasi. Ismail al-Faruqi mengungkapkan bahwa hakikat dakwah adalah kebebasan, universal, dan rasional.

Dakwah tidak dapat dipisahkan dari komunikasi. Dakwah identik dengan proses komunikasi. Proses dakwah merupakan bentuk komunikasi itu sendiri tetapi bukan hanya sebatas komunikasi semata. Dakwah merupakan bentuk komunikasi yang khas. Adapun yang membedakan dakwah dari bentuk komunikasi yang lain adalah cara dan tujuan yang ingin dicapai.

Tujuan dari komunikasi mengharapkan adanya partisipasi dari komunikan atas ide-ide atau pesan yang disampaikan sehingga dengan pesan- pesan tersebut terjadi perubahan sikap dan tingkah laku, demikian juga dengan dakwah. Seorang da'i sebagai komunikator sangat berharap agar pendengarnya sebagai komunikan dapat berbuat dan bersikap sesuai isi pesan yang disampaikan. Dakwah melalui media televisi dapat digolongkan sebagai salah satu bentuk komunikasi massa.

Komunikasi massa melalui media televisi adalah proses komunikasi antara komunikator dengan komunikan (massa) melalui sebuah sarana, yaitu televisi. Daya tarik media televisi demikian besar sehingga pola-pola kehidupan manusia sebelum dan setelah munculnya televisi berubah drastis. Media televisi saat ini menjadi panutan baru (news religius) dan menciptakan budaya popular di sekitar kita. Dalam budaya ini kandungan media condong ke arah apa yang penonton televisi pertimbangkan sebagai sesuatu yang paling menarik, atau yang menjadi pusat perhatian ( Limburg, 2008: 174).

Di Indonesia terdapat beberapa program yang ditayangkan televisi melanggar batasan norma agama dan masyarakat. Program-program tersebut belum terlepas dari isinya yang cenderung mengarah kepada pelecehan agama dan norma sosial yang ditampilkan dalam sebuah acara. Para produsen program di berbagai stasiun TV menangkap peluang, bahwa pencegahan perusakan moral dari televisi tidak hanya dilakukan pada perubahan fisik, tetapi juga harus dilakukan pada segi "psikologis khalayak" yang menikmati program siaran-siaran di televisi. 
Wulan Furrie, Program Serambi Islami Edisi Jum'at Pada Sesi Teletilawah....

Bentuk peluang dan peran produsen program dapat dilihat dengan maraknya program siaran yang bernuansa dakwah Islami, yang saat ini banyak bermunculan. Langkah seperti ini diharapkan mampu memberi alternatif tontonan bermanfaat kepada para khalayak sebagai pemenuhan informasi dan pencerahan untuk lebih meningkatkan keimanan dan takwanya.

Bagi orang Islam membaca Alquran dengan tartil adalah wajib dan mempelajari kitab suci Alquran tidak boleh sembarangan. Dalam surat Almuzammil ayat 4 dijelaskan bahwa membaca Alquran haruslah dengan tartil. Membaca Alquran secara tartil akan membuat setiap muslim akan mendapat manfaat, makna, dan juga keutamaan di dalamnya. Membaca Alquran tidak boleh sembarangan. Ada Ilmu-Ilmu yang harus dipelajari terlebih dahulu.

Ali bin Abi Thalib, sahabat Rasulullah SAW menjelaskan bahwa tartil dapat dimaknai dengan membaca setiap huruf serta tajwid dan juga mengerti tempat berhenti di dalam membaca Alquran. Dalam membaca Alquran haruslah mengerti kapan untuk menyambung bacaan dan mengerti kapan harus berhenti. Makna membaca Alquran dengan tartil menurut $\mathrm{Abu}$ Ishaq adalah membaca Alquran secara jelas. Tartil dapat dimaknai dengan membaca Alquran dengan jelas, antara huruf per hurufnya.

Seorang muslim yang membaca Alquran dengan tartil dapat memahami kalam Allah SWT yang tertuang di dalam ayat yang dibaca tersebut. Dengan membaca secara tartil juga akan membantu bagi seorang muslim yang baru belajar membaca Alquran. Manfaat lain dari membaca Alquran secara tartil akan dapat diketahui bila terdapat kesalahan-kesalahan di dalam membaca. Dengan begitu muslim lain yang juga sedang menyimak bacaan Alquran dapat membenarkan akan kesalahan bacaan yang dilakukan.

Mengingat pentingnya kewajiban membaca Alquran secara tartil dan TV adalah sebuah media dakwah yang sangat strategis, Penulis memilih program acara Serambi Islami edisi jumat pada sesi teletilawah sebagai bahan penelitian. Program Serambi Islami tayang pada pukul 04.30-6.00 WIB dan disiarkan secara langsung (live). Program tersebut dipandu oleh seorang host dan nara sumber yang terdiri dari tiga pakar di bidang seni membaca Alqur'an. Ketiganya tidak hanya memiliki kompetensi yang baik dalam bidang seni membaca Alquran tetapi mereka adalah qori Internasional yang sudah teruji secara prestasi. Acara ini secara keseluruhan berdurasi 1,5 jam dan dibagi menjadi 2 sesi. Sesi pertama adalah teletilawah (45 Menit) sesi ke 2 adalah hikmah pagi (45 Menit). Setiap episode dihadiri oleh audiens dari berbagai majelis taklim di Indonesia dengan jumlah kurang lebih 50 sampai dengan 60 orang. Berdasarkan uraian di atas peneliti ingin mengetahui bagaimana upaya TVRI untuk meningkatkan pengetahuan membaca Alquran secara tartil bagi pemirsa?

\section{TINJAUAN PUSTAKA}

Televisi berasal dari dua kata yang berbeda asalnya, yaitu tele (bahasa 
Yunani) yang berarti jauh, dan visi (videre-bahasa Latin) berarti penglihatan (Wahyudi, 1986: 49). Televisi yang dalam bahasa Inggris television diartikan dengan melihat jauh. Melihat jauh dalam hal ini diartikan dengan gambar dan suara yang diproduksi di suatu tempat (studio televisi) dapat dilihat dari tempat lain melalui sebuah perangkat penerima (televisi set). Menurut Effendy, siaran televisi merupakan media dari jaringan komunikasi dengan ciri-ciri yang dimiliki komunikasi massa, yaitu berlangsung satu arah, komunikatornya melembaga, pesannya bersifat umum, sasarannya menimbulkan keserempakan dan komunikannya bersifat heterogen (Effendy, 2006: 21). Televisi saat ini tidak hanya sekedar membuat program yang mengisi jadwal tayang setiap harinya tetapi juga memerhatikan penggunaan dan penyebaran kontennya, berdasarkan perorangan maupun berkelompok, dengan beragam tampilan, melintasi waktu, dan tuntutan dari beragam lokasi dan pilihan interaktif dari penonton saat ini (Bondad-Brown, Rice, \& Pearce, 2012: $1)$.

\section{Program Televisi}

Kata "program" berasal dari kata dalam bahasa Inggris programme atau program (programmemerupakan penulisan gaya Inggris sedangkan program merupakan penulisan gaya Amerika) yang berarti acara atau rencana. Program adalah segala hal yang ditampilkan stasiun penyiaran untuk memenuhi kebutuhan audiensnya (Morissan , 2008: 199-200).

\section{Program Religi Televisi}

Ahli psikologis agama Wulf menjelaskan bahwa religi adalah suatu yang dirasakan sangat dalam bersentuhan dengan keinginan seseorang, membutuhkan ketaatan, dan memberikan imbalan atau mengikat seseorang dalam suatu masyarakat. Secara komprehensif, ahli-ahli psikologi agama Glock dan Strak menandaskan bahwa religi adalah sistem simbol, sistem keyakinan, sistem nilai, dan sistem perilaku yang terlambang, yang semuanya berpusat pada persoalan yang dihayati sebagai sesuatu yang maknawati (Nasution dan Mucharram, 2002: 45).

\section{Komunikasi Dakwah}

Komunikasi dapat dianggap sebagai proses menciptakan suatu kesamaan (communness) atau suatu kesatuan pemikiran antara pengirim dengan penerima. Kunci utama dari definisi ini adalah diperlukan kesamaan pemikiran yang dikembangkan antara pengirim dan penerima jika diharapkan terjadi komunikasi.

Ahmad Mobarok dalam buku Psikologi Dakwah mengungkapkan bahwa kegiatan dakwah adalah kegiatan komunikasi, dimana da'i (komunikator) mengkomunikasikan pesan dakwah kepada mad'u (komunikan) baik secara perorangan ataupun kelompok. Semua hukum yang berlaku dalam ilmu komunikasi berlaku juga dalam dakwah, dan mengungkapkan apa yang tersembunyi dibalik prilaku manusia. Komunikasi sifatnya lebih netral dan 
umum, sedangkan dakwah terkandung nilai kebenaran dan keteladanan Islam.

Apabila kita menelaah komunikasi dakwah dengan pendekatan komunikologis maka harus diteropong dalam pendekatan dimensi das sein, das sollen, dan das woslen serta dalam ruang lingkup makro, meso dan mikro yang merupakan entitas dakwah. Konsep komunikasi dakwah dapat dilihat dalam arti yang luas dan tidak terbatas. Dalam arti luas komunikasi dakwah memiliki peran dan fungsi komunikasi di antara semua pihak yang terlibat dalam dakwah terutama da'i dan mad'u, sejak dari proses perencanaan, pelaksanaan dan penilaian terhadap dakwah.

Dalam arti sempit, komunikasi dakwah merupakan segala upaya dan cara, metode serta teknik penyampaian pesan dan keterampilan-keterampilan dakwah yang ditujukan kepada umat dan masyarakat luas. Jadi komunikasi dakwah adalah proses penyampaian informasi atau pesan dari seseorang atau sekelompok orang kepada seseorang atau sekelompok orang lainnya yang bersumber dari Alquran dan hadis dengan menggunakan lambang-lambang baik secara verbal maupun non-verbal dengan tujuan untuk mengibah sikap, pendapat atau perilaku orang lain yang lebih baik sesuai ajaran Islam, baik langsung secara lisan maupun tidak langsung melalui media.

\section{Kebutuhan Spiritual}

Kebutuhan spiritual adalah harmonisasi dimensi kehidupan. Dimensi ini termasuk menemukan arti, tujuan, menderita, dan kematian; kebutuhan akan harapan dan keyakinan hidup, dan kebutuhan akan keyakinan pada diri sendiri, dan Tuhan. Ada lima dasar kebutuhan spiritual manusia yaitu: arti dan tujuan hidup, perasaan misteri, pengabdian, rasa percaya dan harapan di waktu kesusahan (Hawari, 2002: 10).

Kebutuhan spiritualisme merunjuk kepada kesadaran pribadi seorang manusia mengenai hal-hal yang bersifat indrawi, tidak dapat dilihat nyata yang berasal dari perasaan, pikiran, maupun yang dihasilkan secara naluriah alat indera. Salah satu aspek spiritual adalah mencapai hubungan yang lebih dekat dengan ketuhanan, dimana dalam hal ini dikaitkan dengan agama yang diyakini setiap individu sebagai praktik nyata untuk memenuhi kebutuhan spiritualismenya. Dengan demikian dapat disimpulkan bahwa spiritualisme memberikan jawaban siapa dan apa seseorang itu (keberadaan dan kesadaran), sedangkan agama memberikan jawaban apayang harus dikerjakan seseorang (prilaku atau tindakan).

Kebutuhan Spiritual dalam penelitian ini difokuskan kepada kebutuhan spiritual bagi umat islam yang dijabarkan kedalam tiga dimensi yang mencakup dimensi vertikal dan dimensi horizontal sebagai berikut:
a. Amalan
spiritual, diantaranya sholat, berdoa, dzikir, dan tafakur.
b. Makna kehidupan, berhubungan dengan kebaikan dan keburukan.
c. Keseimbangan hidup, berhubungan dengan ketenagan hati dan pikiran.


Dari ketiga dimensi tersebut, kebutuhan spiritual mengenai hal-hal yang berkaitan dengan membaca Alquran dengan baik dan benar ( sesuai kaidah yang di Ajarkan oleh Rosulullah SAW), disampaikan dalam sebuah program dakwah Islam dalam format interaktif dengan pemirsa, yaitu program Serambi Islam sesi Teletilawah. Informasi-informasi dakwah ini terdiri dari himbauan untuk membaca Alquran secara tartil, bersabar untuk mempelajarinya, selalu memiliki semangat untuk membaca Alquran dan mempelajari manfaat dari membaca Alquran secara tartil.

\section{Membaca Alquran Secara Tartil}

Alquran sebagai Kalam Allah SWT haruslah menjadi pedoman umat muslim dalam menjalani kehidupan di dunia. Setiap ayat di dalam Alquran memiliki arti yang perlu dimaknai, dihayati, dan diterapkan dalam kehidupan. Di dalam Alquran tersebut dengan jelas apa saja yang menjadi perintah dan larangan dari Allah SWT kepada hamba-Nya. Untuk itulah Alquran sebaiknya dibaca secara tartil.

\section{Bacalah Alquran Secara Tartil}

Disebutkan dalam Al-Muzammil ayat 4 bahwa ketika umat muslim membaca Alquran, hendaknya dibaca secara tartil. Tartil memiliki makna dibaca berdasarkan ilmu tajwid. Tajwid artinya setiap ayat-ayat Alquran dibaca dengan lafal yang bagus dan mengikuti dengan tepat di mana saja hendaknya berhenti ketika membaca Alquran. Makna tartil tersebut hendaknya dipahami umat muslim sebaga membaca Alquran dengan sikap tenang, tidak terburu-buru, setiap ayat demi ayat Alquran dibaca dengan jelas. Membaca Alquran secara bagus didasari pula pada dapat membaca ayat demi ayatnya dengan benar dan jelas. Mengingat setiap ayat tersebut adalah Kalam Allah SWT yang harus dilafalkan dengan penuh penghayatan.

\section{Membaca Alquran Secara Tartil Membawa Keutamaan}

Membaca Alquran secara tartil akan memberikan keutamaan bagi umat muslim. Menurut sabda Rasulullah SAW bahwa akan diberikan kepada kita satu kebaikan ketika membaca satu huruf Alquran dan dilipatgandakan sepuluh kali kebaikan yang diterima. Artinya adalah ketika umat muslim membaca satu huruf saja yang ada dalam Alquran secara tartil, maka mereka akan memperoleh keutamaan berupa satu kebaikan atau satu pahala. Satu pahala tersebut kemudian menjadi dilipatgandakan sebanyak sepuluh pahala. Sehingga semakin banyak huruf Alquran yang dibaca secara tartil maka akan semakin banyak pula pahala yang diperoleh.

Sebagai umat muslim tidak sekadar dituntut untuk mau membaca Alquran tapi juga pandai membaca ayat demi ayat Alquran secara tartil. Pahala yang Allah SWT berikan dapat menjadi amal sholeh untuk kehidupan di dunia maupun di akherat. Sudah jelas disebutkan dalam Quran Surat Faathir ayat 29-30, "Allah SWT akan memberikan anugerah bagi umat-Nya 
Wulan Furrie, Program Serambi Islami Edisi Jum'at Pada Sesi Teletilawah....

yang mau membaca dengan mengharap pahala".

\section{Teori Hirarki Pengaruh Isi Media}

Teori hirarki pengaruh isi media (Theories of influences on Mass Media Content) diperkenalkan oleh Pamela J Shoemaker dan Stephen D. Reese.Teori ini menjelaskan tentang pengaruh terhadap isi media pada suatu pemberitaan, baik dari pengaruh internal dan maupun eksternal. Shoemaker dan Reese membagi kepada beberapa level pengaruh isi media yaitu pengaruh dari individu pekerja media (individual level), pengaruh dari rutinitas media (media routines level), pengaruh dari organisasi media (organizational level), pengaruh dari luar media (outside media level), dan yang terakhir adalah pengaruh ideologi (ideology level). (Shoemaker, 1996:60).

Kajian isi media massa harus didasarkan asumsi bahwa isi pesan media bukanlah cerminan realitas masyarakat. Selalu ada faktor-faktor yang memengaruhi isi media tersebut.

Gambar 1. Teori Hirarki Pengaruh Isi Media

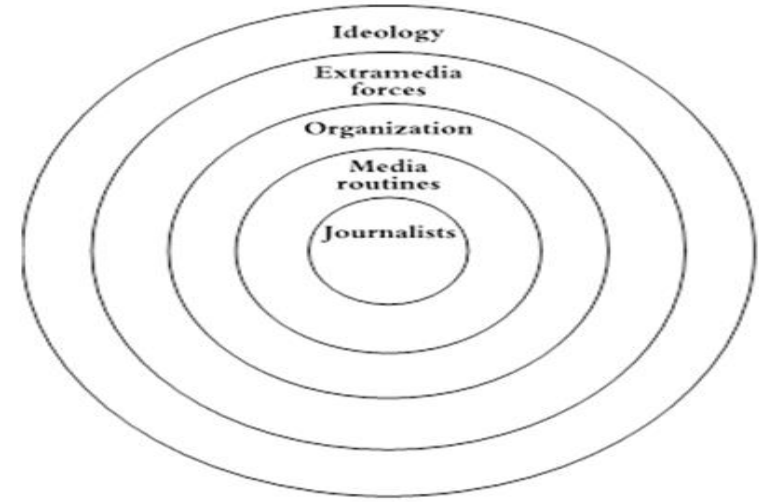

1. Level pengaruh individu pekerja media (Journalist)

Faktor latar belakang dan karakteristik dari pekerja media, faktor prilaku dan kepercayaan seorang jurnalis serta orientasi dari jurnalis tersebut. Faktor latar belakang jurnalis tersebut menurut Shoemaker dan Resse dibentuk oleh beberapa faktor seperti gender, jenis kelamin, etnis dan orientasi seksual, faktor pendidikan dan dari manakah jurnalis tersebut, dari golongan kebanyakan atau golongan elit.
2. Level Rutinitas Media (Routinitas media)

Rutinitas media adalah kebiasaan dalam pengemasan sebuah berita/program. Media rutin terbentuk oleh tiga unsur yang saling berkaitan yaitu sumber berita (processor), organisasi media (Suplier) dan audiens (Consumer). Ketiga unsur ini saling berhubungan dan akhirnya membentuk rutinitas media.

3. Level pengaruh Organisasi (organization) 
Level organisasi berkaitan dengan level struktur organisasi pada sebuah media, kebijakan dan tujuan sebuah media. Level organisasi lebih berpengaruh dibanding level sebelumnya (pekerja media dan rutinitas). Hal ini karena kebijakan terbesar dipegang oleh pemilik media melalui editor pada sebuah media. Penentu kebijakan menentukan sebuah pemberitaan/program tetap dipegang oleh pemilik media. Kebijakan pemilik media lebih kuat dibanding pekerja media dan rutinitas.

4. Level pengaruh luar organisasi media (extra media force)

Pengaruh ke-empat dalam teori ini adalah pengaruh dari luar organisasi media atau yang biasa disebut denngan extra media level/ extra media force. Sumber dari luar media itu sumber berita, pengiklanan dan penonton, kontrol dari pemerintah, pangsa pasar dan teknologi.

5. Level pengaruh Ideologi

Adalah kerangka berfikir tertentu yang dipakai oleh individu untuk melihat realitasdan bagaimana mereka menghadapinya. Berbeda dengan level individu yang sebelumnya yang tampak konkret, level ideologi ini abstrak. Level ini berhubungan dengan konsepsi atau posisi seseorang dalam menafsirkan realitas dalam sebuah media. Pembahasan pada level ini adalah mempelajari hubungan antara pembentukan konten media nilanilai, kepentingan dan relasi kuasa media. Pada kekuatan ideologi ini kita belajar lebih dekat pada kekuatan di masyarakat dan mempelajari bagaimana kekuatan yang bermain diluar media. Kita berasumsi bahwa ide memiliki hubungan dengan kepentingan dan kekuasaan.

Asumsi dari teori hirarki pengaruh isi media adalah bagaimana isi pesan media yang disampaikan kepada khalayak adalah hasil pengaruh dari kebijakan internal organisasi media dan pengaruh dari eksternal media itu sendiri. Pengaruh internal pada konten media sebenarnya berhubungan dengan kepentingan dari pemilik media, individu wartawan sebagai pencari berita, rutinitas organisasi media. Faktor eksternal yang berpengaruh pada konten media berhubungan dengan para pengiklan, pemerintah masyarakat, dan faktor eksternal lainnya.

Reese (1991) mengemukakan bahwa isi pesan media atau agenda media merupakan hasil tekanan yang berasal dari dalam dan luar organisasi media. Dengan kata lain, isi atau konten media merupakan kombinasi dari program internal, keputusan manajerial dan editorial, serta pengaruh eksternal yang berasal dari sumber-sumber nonmedia, seperti individu-individu berpengaruh secara sosial, pejabat pemerintah, pemasang iklan, dan sebagainya.

Dari teori ini akan terlihat seberapa kuat pengaruh yang terjadi pada tiap-tiap level. Contohnya, pengaruh level ideologi yang terjadi pada sebuah isi sebuah media, walaupun 
Wulan Furrie, Program Serambi Islami Edisi Jum'at Pada Sesi Teletilawah....

dianggap abstrak tapi sangat memengaruhi sebuah media karena brsifat tidak memaksa dan bergerak di luar kesadaran keseluruhan organisasi media itu sendiri.

\section{METODE PENELITIAN}

Penelitian ini menggunakan metode kualitatif deskriptif. Metode penelitian kualitatif yaitu prosedur penelitian yang menghasilkan data deskriptif berupa kata-kata tertulis atau lisan dari orang-orang dan perilaku yang dapat diamati (Moleong,2010). Fokus penelitian ini adalah pada upaya TVRI dalam meningkatkan kemampuan membaca Alquran secara tartil bagi pemirsanya. Penelitian dilakukan dimulai dari pra produksi, produksi hingga pasca produksi.

Sumber data penelitian diambil dari data primer ( wawancara mendalam dan observasi) dan data sekunder (dokumen/arsip yang diperoleh sebagai data pendukung). Teknik pengumpulan data yang dipakai adalah observasi dan wawancara mendalam.

Dalam menguji kredibilitas hasil data, peneliti menggunakan teknik triangulasi. Teknik triangulasi yang digunakan peneliti adalah triangulasi sumber dan triangulasi metode. Triangulasi sumber yakni dengan memeriksa dan membandingkan data yang telah diperoleh dari satu sumber data dengan beberapa data lain. Data yang dimaksud adalah data dari informan yang akan diperiksa melalui informan satu dengan informan lainnya. Triangulasi metode adalah mengumpulkan data yang diperoleh dari observasi dan wawancara mendalam terhadap informan.

\section{HASIL DAN PEMBAHASAN}

Televisi Republik Indonesia (TVRI) merupakan lembaga penyiaran pertama di Indonesia. TVRI berdiri pada tanggal 24 Agustus 1962 dan bertugas untuk mengemban tugas sebagai televisi yang mengangkat citra bangsa. Melalui Undang-Undang Republik Indonesia Nomor 32 Tahun 2002 tentang Penyiaran, TVRI ditetapkan sebagai Lembaga Penyiaran Publik yang berbentuk badan hukum yang didirikan oleh Negara. Berdasarkan Peraturan Pemerintah RI Nomor 13 Tahun 2005 ditetapkan bahwa tugas TVRI adalah memberikan pelayanan informasi, pendidikan dan hiburan yang sehat, kontrol dan perekat sosial, serta melestarikan budaya bangsa untuk kepentingan seluruh lapisan masyarakat melalui penyelenggaraan penyiaran televisi yang menjangkau seluruh wilayah Negara Kesatuan Republik Indonesia.

Sebagai media antara masyarakat dan pemerintah Indonesia, TVRI memiliki visi untuk menjadi media pilihan bangsa Indonesia dalam rangka turut mencerdaskan kehidupan bangsa untuk memperkuat kesatuan nasional. Adapun untuk mewujudkannya, berikut adalah Misi TVRI:

1. Mengembangkan TVRI menjadi media perekat sosial untuk persatuan dan kesatuan bangsa sekaligus media kontrol sosial yang dinamis.

2. Mengembangkan TVRI menjadi pusat layanan informasi dan edukasi yang utama. 
3. Memberdayakan TVRI menjadi pusat pembelajaran bangsa serta menyajikan hiburan yang sehat dengan mengoptimalkan potensi dan kebudayaan daerah serta memperhatikan komunitas terabaikan.

4. Memberdayakan TVRI menjadi media untuk membangun citra bangsa dan negara Indonesia di dunia internasional.

Program Serambi Islami edisi Jumat tayang pada pukul 04.30-6.00 (Sesi teletilawah 04.30-05.15) WIB adalah sebuah tayangan yang turut serta dalam memberikan pendidikan membaca Alquran secara baik dan benar (tartil) sesuai tuntunan Rasulullah SAW bagi pemirsanya. Hal ini selaras dengan visi dan misi yang dimiliki oleh TVRI, yakni mencerdaskan kehidupan bangsa.

Program ini diproduksi berdasarkan Kerangka Acuan Kerja (KAK) produksi paket acara Serambi Islami, memiliki latar belakang bahwa Islam adalah agama dakwah, yaitu agama yang menugaskan umatnya untuk menyebarkan dan menyiarkan Islam kepada seluruh umat manusia sebagai rahmat bagi seluruh alam. Usaha untuk menyebarkan Islam dan merealisasikan ajarannya di tengahtengah kehidupan umat manusia merupakan usaha dakwah Islam dalam keadaan bagaimanapun dan dimanapun. Melalui program Teletilawah kita dapat mengetahui dan membahas permasalahan serta kesalahan yang terjadi ketika membaca Alquran secara jarak jauh. Waktu yang disediakan tidak akan mewakili keinginan dari pemirsa (45 menit). Setidaknya program ini bisa menjadi trigger (pemicu) bagi pemirsa yang masih harus membenahi bacaan Alquran-nya. Nara sumber di setiap episode selalu mengingatkan pemirsa untuk sedapat mungkin berhadapan langsung dengan guru yang memiliki kompetensi yang baik dalam bidang membaca Alquran sehingga kesalahan bisa langsung diketahui, dalam istilah arab disebut Tallaqi Musyafahah.

Upaya TVRI untuk mewujudkan program ini dapat dibagi ke dalam 3 keadaan/kondisi (Pra produksi, Produksi dan Pasca Produksi)

\section{Pra Produksi}

1. Ide

Ide agar masyarakat memiliki tayangan yang bermutu dan bermanfaat serta belum adanya tayangan membaca Alquran secara tartil di statiun TV swasta dengan metode jarak jauh (melibatkan pemirsa di rumah) yang disebut TVRI dengan Teletilawah. Kondisi ini menggerakkan TVRI untuk bisa memberikan tayangan tersebut kepada pemirsa.

Setelah ide diajukan oleh produser kemudian ide tersebut dikomunikasikan kepada pimpinan (Kepala bidang Program). Produser menuangkan ide ke dalam sebuah proposal dan mempresentasikannya. Setelah adanya persetujuan dilakukan perancangan Kerangka Acuan Kerja ( KAK ), pembentukan kerabat kerja, pembentukan tim artistik, pemilihan nara sumber dan host, perancangan naskah (script) dan rundwon. 
Wulan Furrie, Program Serambi Islami Edisi Jum'at Pada Sesi Teletilawah....

\section{Perancangan Kerangka Acuan Kerja}

\section{( KAK )}

Perancangan KAK( Kerangka Acuan Kerja) berjalan paralel dengan persiapan produksi. KAK adalah sebuah acuan kerja yang nantinya dipakai sebagai landasan dalam pelaksanaan produksi. KAK dibuat oleh produser/pengarah acara, dan diketahui oleh kepala bidang program dan Kepala Seksi Produksi Program. Di dalam KAK terdapat hal- hal yang harus dijadikan acuan kerja bagi seluruh pihak yang terlibat dalam pembuatan Produksi paket acara Serambi Islami, yaitu: latar belakang, maksud dan tujuan, target sasaran, nama organisasi pengadaan barang/jasa, sumber dana dan perkiraan biaya, ruang lingkup pengadaan, lokasi dan fasilitas penunjang, produk yang dihasilkan,waktu pelaksanaan yang diperlukan, tenaga terampil yang dibutuhkan, metode, spesifikasi teknis, laporan kemajuan.

\section{Pembentukan Kerabat Kerja}

Setelah KAK rampung, rapat pra produksi diinisiasi oleh produser untuk mengkoordinasikan seluruh pendukung produksi, yaitu menentukan Produser Pelaksana (Assistant Produser), Sutradara/Pengarah Acara (Programme Director), Asisten Pengarah Acara/Asisten Sutradara (Assistant Director), Pengarah Lapangan (Floor Director), Pengarah Panggung (Stage Manager), Pimpinan Unit (Unit Manager) dan Tim kreatif.

Berdasarkan Rencana Produksi (RPA), maka terbentuklah kerabat kerja dan disahkan melalui Surat Perintah Kerja Produksi (SPKP). Setelah SPKP keluar Kepala Program Bidang membuat surat permohonan Kerabat Kerja dan peralatan produksi yang ditujukan kepada Kepala bidang Teknik Produksi dan Penyiaran. Tembusan ditujukan pada Direktur Program dan Berita (Sebagai Laporan), Kepala Bidang Penunjang Program dan Berita, Kepala Bidang Transmmisi, Kepala Bidang Tekhnologi Informatika dan Tekhnik, Kepala Bagian sarana dan Prasarana, Para Koordinator dilingkungan Seksi Produksi Program.

\section{Pembentukan Tim Artistik}

Petugas tim artistik terdiri dari Desainer panggung, Dekorasi, Properti dan make up. Desainer panggung dan dekorasi bertugas untuk mendesain dekorasi layout panggung (area syuting). Properti bertugas untuk mengisi hiasan sebagai pelengkap dekorasi sedangkan petugas make up akan menjalankan fungsinya sebagai tim yang akan mendandani wajah semua pengisi acara.

Setelah petugas artistik terbentuk, produser memberikan gambaran desain layout kemudian beberapa orang kreatif yang tergabung dalam tim artistik menciptakan dan mengembangkan ide serta menuangkannya dalam bentuk gambar/desain untuk dekorasi panggung (area syuting) kemudian panggung diisi oleh back drop dan property. Setelah semua letak properti dipastikan sesuai yang diinginkan maka setting lighting, audio dan blocking kamera-pun di lakukan. 


\section{Gambar 2. Desain Panggung}

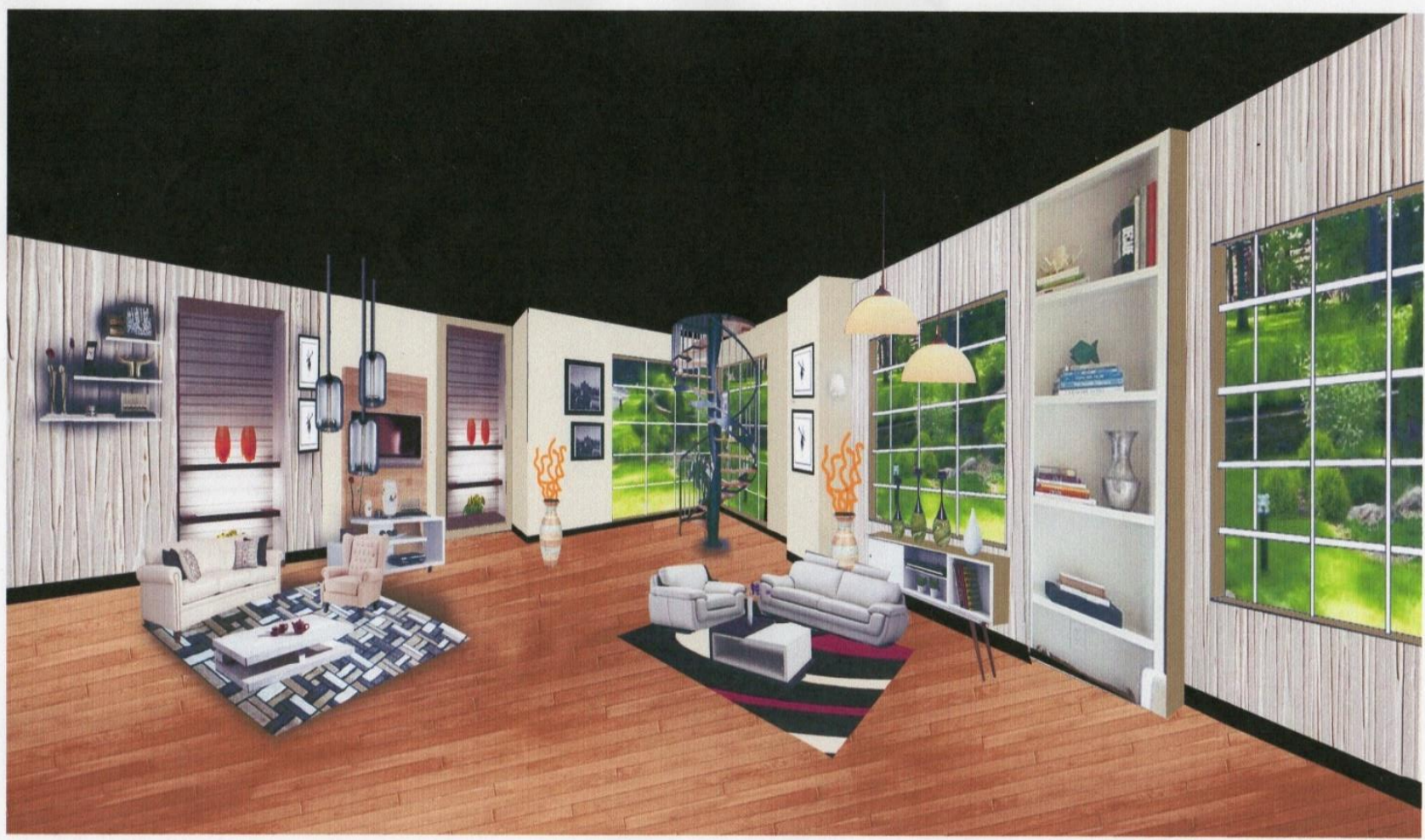

5. Nara Sumber

Nara sumber yang akan tampil dalam acara ini dicari melalui referensi yang terpercaya. Karena program ini berkaitan erat dengan membaca Alquran dengan kualitas terbaik maka nara sumber yang akan dijadikan evaluator bagi pemirsa juga harus memiliki prestasi yang telah teruji dan diakui secara nasional/ internasional. Kandidat nara sumber misalnya mempunyai prestasi sebagai pembaca terbaik MTQ nasional, juara MTQ Internasional di Mekkah, dosen di Institut Perguruan Tinggi Ilmu Qur'an (PTIQ), juara
Seleksi Tilawah Qur'an (STQ) Nasional, dan sebagainya.

\section{Host ( Pembawa Acara )}

Pembawa acara dipilih melalui audisi yang panjang dengan memenuhi persyaratan yaitu : performa, pengetahuan agama, dan keterampilan membaca Alquran.

\section{Audiens}

Audiens sebelumnya mendaftar kemudian akan diseleksi oleh tim. Tim menghubungi jamaah taklim yang tepilih dengan kriteria bukan dari jamaah yang memiliki paham 
Wulan Furrie, Program Serambi Islami Edisi Jum'at Pada Sesi Teletilawah....

kontradiktif dengan akidah islam, siap berpakaian rapi, sanggup hadir pada pukul 04.00 WIB.
8. Pembuatan Rundown

Rundwon dibuat oleh pengarah acara atas ide produser.

Tabel 1 . Rundwon Acara Serambi Islam

\section{IUNCOWN SERAMBI ISLAMI}

\begin{tabular}{|c|c|c|c|c|c|c|}
\hline SEG & NO & PKL & DUR & VIDEO & AUDIO & KET. \\
\hline & 1. & 04.30 .00 & $00^{\prime} 20^{\prime \prime}$ & Tune SERAMBI ISLAMI & PBVT & \\
\hline & 2. & 04.30 .20 & $01^{\prime} 00^{\prime \prime}$ & $\begin{array}{l}\text { Opening Host: WULAN FURRIE LENGGANA } \\
\text { Host tag to TELETILAWAH }\end{array}$ & Live Sto & \\
\hline & 3. & 04.31 .20 & $01^{\prime} 00^{\prime \prime}$ & $\begin{array}{l}\text { Host opening TILAWAH } \\
\text { Memperkenalan Narsum dan macro ayat: } \\
\text { 1. H. Sofyan Hadi, MA. } \\
\text { 2. H. Imron Rosyadi ZA. }\end{array}$ & Live Sto & \\
\hline & 4. & 04.32 .20 & $09^{\prime} 10^{\prime \prime}$ & $\begin{array}{l}\text { Host mempersilakan Narsum membaca Al Quran } \\
\text { Macro : Q.S. Al Maa'idah ayat } 36 \\
\text { Qori } \quad \text { : H. Sofyan Hadi, MA. }\end{array}$ & Live Sto & \\
\hline & & 04.41 .30 & $00^{\prime} 30^{\prime \prime}$ & $\begin{array}{l}\text { Host tag to Adzan Subuh } \\
\text { Bridging Serambi Islami }\end{array}$ & & \\
\hline & 5. & 04.42 .00 & $09^{\prime} 00^{\prime \prime}$ & ADZAN SUBUH/ASMAUL HUSNA/COMBREAK/BRIDGING OUT & $P C / N T$ & \\
\hline 4 & 6. & 04.51 .00 & $14^{\prime} 00^{\prime \prime}$ & $\begin{array}{l}\text { - Host mengajak jama'ah di studio \& pemirsa untuk belajar } \\
\text { membaca Al Qur'an Via telepon interaktif: } \\
5743476 \text { / O21 - } 5643478 \\
\text {-Narsum memberikan komentar/koreksi } \\
\text {-Kesimpulan \& Clossing Host } \\
\text {-Host mengantar ke Hikmah Pagi dan Combreak }\end{array}$ & & \\
\hline & 7. & 05.05 .00 & $00^{\prime} 20^{\prime \prime}$ & Graphis Hadist 2 & PB VT & \\
\hline & 8. & 05.05 .20 & $02^{\prime} 00^{\prime \prime}$ & Bridging Serambi Islami/Combreak 2 / Bridging SI & $V T / P C / S t_{0}$ & \\
\hline
\end{tabular}

ADZAN : 04.42 WIB

Pkl. : $04.30-06.00$ WIB 
( host berjalan melewati melewati tangga menuju kamera 1. Pause digaris yang telah ditentukukan)

\section{Opening Host :}

Bismillahirrahmanirrahim...

Assalamualaikum warohmatullahi wabarakatuh...

Apa kabar pemirsa..., Semoga hari ini kita semua dalam keadaan sehat walafiat.. dan Anda beserta keluarga selalu berada dalam lindungan Allah SWT. Syukur alhamdulillah pemirsa hari ini kita bisa kembali berjumpa dalam sebuah tayangan program yang membuat kita lebih mencintai Alquran. Kami akan mengajak Anda membaca Alquran secara tartil, sesuai dengan apa yang diperintahkan Alquran dalam surat al Muzammil ayat 4 yang berbunyi: warrotirilqurana.. tartilla.., yang artinya.. bacalah Alquran dengan tartil.

Oleh karena itu pemirsa..kami mengajak anda untuk memperbaiki bacaan Alquran Anda bagi yang belum tartil, dan syukur alhamdulillah bagi Anda yang sudah membaca Alquran secara tartil...Anda bisa membantu saudara-saudara kita yang masih harus berada dalam bimbingan seorang mursyid atau guru membaca Alquran untuk bertallaqi Musafahah.

Pemirsa...Anda bisa menghubungi kami di 5743476/021-5743478 dengan makro hari ini yaitu, Alquran surat Almaidah ayat 35, jangan lupa untuk menyebutkan passwordnya terlebih dahulu.." CINTA..QUR'AN".

(Kemudian host berjalan menghampiri kursi narsum dan menyapa audiens/ jamaah)

Host : Assalamualaikum Ustadz Imron dan Ustadz Sofyan.. apa kabar ? Trimakasih ustadz..sudah berada disini untuk dapat mengevaluasi bacaan Quran dari pemirsa..

Narsum : Walaikumsallam.. iya.. Syukur alhamdulillah.., terimakasih

Host menyapa kepada Jamaah : Assalamualaikum bapak ibu.. apa kabar ?, dst.

Jamaah : Alhamdulillah

04.32.20 (09’10”)

Host mempersilahkan Narsum membaca contoh bacaan Quran untuk pemirsa ( Q.S Al maidah ayat 35, oleh Ustdz Imron Rosyadi ZA )

Baik pemirsa sebelum kami menerima telepon dari Anda.., kita dengarkan telebih dahulu bacaan Quran yang akan disampaikan oleh Ustdz : Imron Rosyadi ZA.., Silahkan Ustadz...

( Setelah Narsum membacakan contoh bacaan...)

Host : Baiklah pemirsa..telah kita dengarkan tadi contoh bacaan yang sudah disampaikan oleh guru kita, Ustadz Imron Rosyadi ZA, kini kami mempersilahkan kepada Anda untuk bisa berpartisipasi...Anda bisa menghubungi kami di line telpon kami: 5743476/021-5743478, jangan lupa untuk menyebutkan passwordnya terlebih dahulu... "CINTAAAAAA... QUR'AN..."

Telp masuk.. Interaktif dengan pemirsa... evaluasi..kemudian

04.41 .30 (00’30”)

Host tag to Azan Subuh 
Wulan Furrie, Program Serambi Islami Edisi Jum'at Pada Sesi Teletilawah....

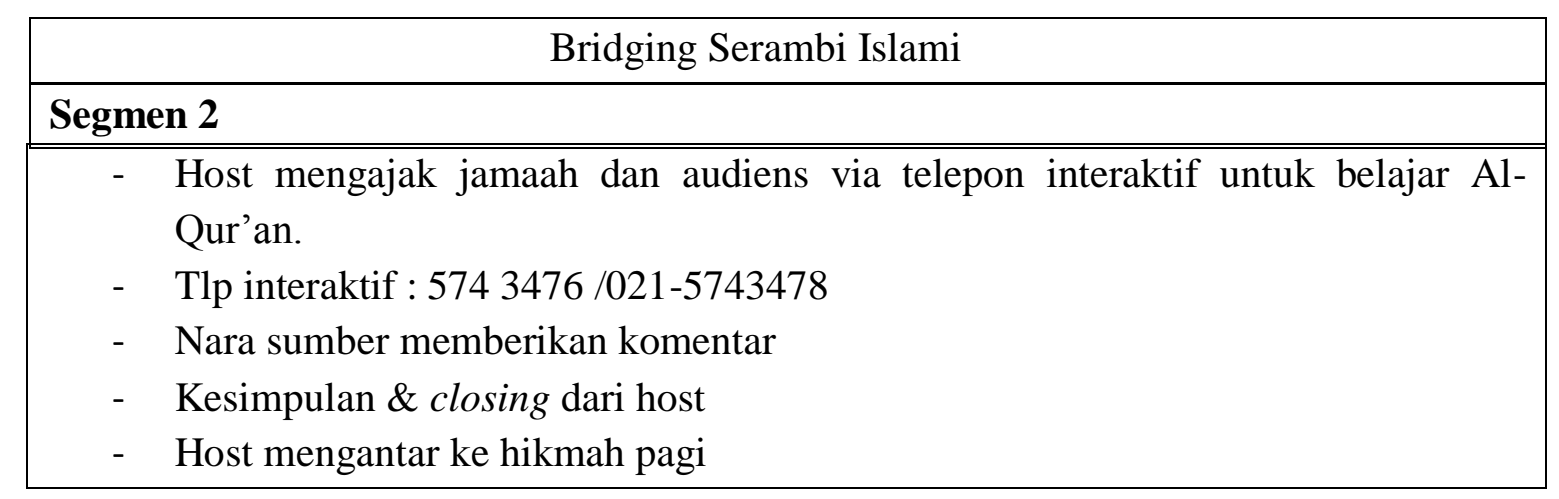

\section{Clossing Host Sesi TELETILAWAH}

Pemirsa demikianlah sesi tilawah kita pada hari Jum'at ini. Kami mengucapkan terimakasih untuk Anda yang sudah berpartisipasi, dan untuk Anda yang kali ini belum punya kesempatan jangan putus asa. Minggu depan kami masih akan kembali untuk Anda. Kami seluruh kerabat kerja yang bertugas, mengucapkan terimakasih atas perhatian Anda. Billahitaufik walhidayah, wassallamualaikum wr.wb.....

Setelah semua rampung pendukung program dicek kembali sebelum pelaksanaan. Pada H-2 diadakan gladi resik untuk memastikan semua sesuai dengan rencana (wajib hadir bagi semua pengisi acara dana Kru )

\section{Produksi}

Pada saat acara kadang-kadang terjadi hambatan karena saluran telepon karena acara ini disaksikan oleh pemirsa seluruh Indonesia dan banyak pemirsa yang ingin berpartisipasi. Ada 2 saluran telepon yang bisa dihubungi di 5743476 / 02195743478 yang dijaga oleh 2 petugas khusus. Setelah petugas menerima telepon, kemudian dicatat dan disambungkan ke studio, host menginformasikan kepada pemirsa. Kesiapan teknis dan antisipasi dilakukan sebelumnya namun demikian kadang-kadang masih terjadi kendala pada penerimaan telepon. Setelah acara selesai dilakukan koreksi dan perbaikan.

Disaat syuting berlangsung, mekanisme acara digambarkan dalam lembar treatment berikut ini 
Tabel 2. Mekanisme Acara Syuting

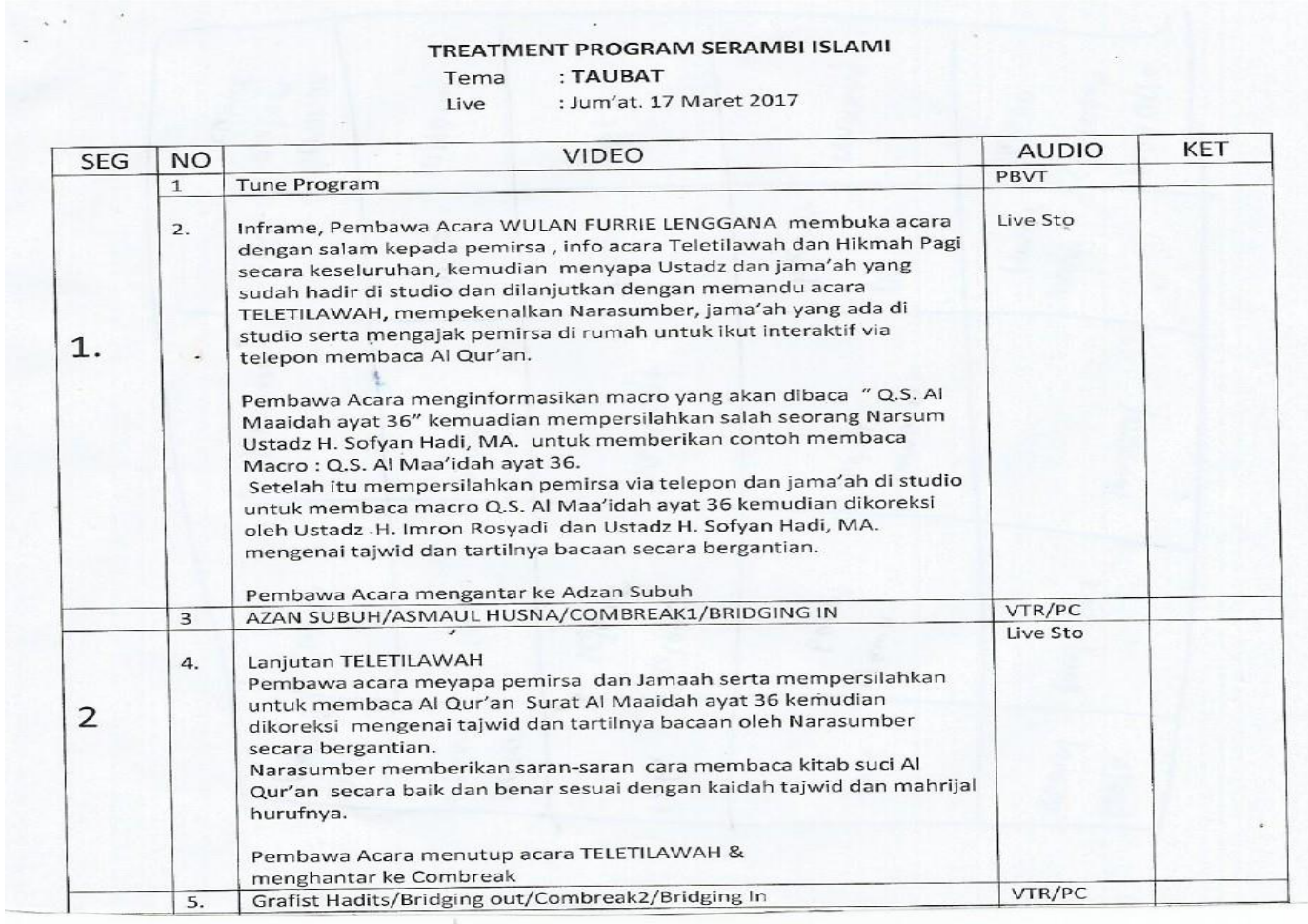

\section{Pasca Produksi}

Pada pasca produksi selalu dilakukan evaluasi, menyangkut audio video dan konten materi. Untuk audio video biasanya langsung disampaikan kepada petugas bersangkutan begitu pula konten / performa yang dibawakan oleh host atau naras umber.

J.shoemaker dan Stephen D.Reese dalam buku Mediating the Message : Theories of influences on Mass Media Content (1996) memandang bahwa telah terjadi pertarungan dalam memaknai realitas dalam isi media. Pertarungan itu disebabkan oleh berbagai faktor, pertama, level pengaruh individu pekerja media, kedua, level rutinitas media, ketiga, level struktur organisasi, keempat, level pengaruh luar organisasi media, serta terakhir, level ideologi.

Asumsi dari teori yang disampaikan oleh Shoemakker dan Resse adalah bahwa isi media yang disampaikan kepada khalayak adalah pengaruh dari kebijakan internal organisasi dan external media. Resee mengemukakan bahwa isi media dan agenda media merupakan tekanan dari dalam dan luar organisasi media.

\section{Level pengaruh individu pekerja media}

Pemberitaan suatu media dan pembentukan konten media tidak terlepas dari faktor individu seorang pencari berita atau jurnalis karena disampaikan dalam teori ini. Salah satu faktor yang membentuk level individual dari teori hirarki pengaruh ini adalah 
faktor latar belakang dan karakteristik jurnalis. Dalam Program Teletilawah ini jurnalis yang dimaksud adalah pemilihan nara sumber yang tepat (dari sisi pendidikan, intelektual, dan prestasi) hingga membentuk faktor nilai-nilai dan kepercayaan pemirsa terhadap nara sumber. Nara sumber dapat memberikan pengetahuan yang benar kepada pemirsa. Selanjutnya inspirasi ini berkembang dan akhirnya program ini bisa dijadikan salah satu alternative panduan bagi pemirsa Indonesia untuk bisa membaca Alquran secara tartil.

\section{Level Media Rutin ( Level rutinitas media)}

Level media rutin terbentuk oleh tiga unsur yang saling berkaitan yaitu sumber berita (suppliers), organisasi media (processor), dan audiens (consumers). Ketiga unsur ini saling berhubungan dan berkaitan dan pada akhirnya membentuk rutinitas media yang membentuk pemberitaan pada sebuah media.(Shoemaker, 1996: 109).

a) Audiens (Consumers)

Kertergantungan kepada audiens sangat besar sehingga dapat menghasilkan keuntungan bagi media. Media sangat memerhatikan pemilihan unsur berita. Program Teletilawah yang disajikan oleh TVRI adalah sebuah program yang dibutuhkan oleh sebagian besar masyarakat Indonesia. Dalam tuntunan Islam, membaca Alquran secara tartil adalah fardhu ain (wajib dilakukan, kalua tidak dilakukan maka berdosa) sama wajibnya dengan mendirikan sholat. TV swasta hingga saat ini belum berinisiatif untuk membuat program teletilawah oleh karena itu TVRI yang memiliki visi turut mencerdaskan kehidupan bangsa membuat program ini atas dasar kebutuhan pemirsa.

b) Organisasi Media (Processor)

Unsur yang paling berpengaruh pada media adalah editor media atau yang biasa disebut Gatekeeper. Editor di setiap media menentukan mana berita yang layak ditulis mana yang tidak. Dalam hal ini yang menjadi Processor dalam pembuatan program hingga tayang adalah Produser. Produser adalah orang yang mempunyai wawasan dan kemampuan dalam menuangkan ide/ pemikiran dalam satu tulisan (proposal) untuk suatu program dengan baik dan sistematis, mempunyai kemampuan memimpin, serta mengkoordinasi seluruh pendukung produksi.

Keputusan yang dibuat produser sangat berpengaruh pada baik buruknya program TELETILAWAH Serambi Islami karena produserlah yang menentukan naskah sesuai dengan idenya, membuat desain produksi, memimpin rapat produksi, menentukan satuan kerja produksi/kelompok kerja produksi. Produser dan pengarah acara memilih dan menentukan pengisi acara, menyusun anggaran produksi, mengawasi proses produksi, melakukan evaluasi terhadap acara yang ditangani, dan sebagainya. 
c) Sumber Berita (suppliers)

Walaupun sumber media tidak terlalu signifikan pengaruhnya kepada media, ketergantungan media kepada sebuah berita sedikit banyak dapat memengaruhi sebuah pemberitaan. Biasanya terdapat simbiosis mutualisme antara pencari berita dengan pemberitaan. Sumber media mendapatkan berita dengan mudah sedangkan lembaga mendapat pencitraan yang baik.

Dalam hal ini Sumber berita adalah tim kreatif yang bertugas menciptakan dan mengembangkan ide dan menuangkannya dalam bentuk desain program. Tim kreatif ini bertugas mempelajari keinginan/kebutuhan masyarakat penonton televisi berdasarkan hasil survei dan pengamatan yang kritis dan peka, melakukan strategi bersaing untuk menyatakan kelemahan, keunggulan kompetitor, mengidentifikasi kekuatan sendiri meliputi SDM, Peralatan, dll. Semua yang dilakukan oleh tim kreatif dipertanggungjawabkan kepada Manajer Perencanaan Produksi. Surat dari pemirsa, antusiasme pemirsa, banyaknya audiens di studio yang ingin berpartisipasi adalah sumber berita yang didapat dari tim kreatif. Sumber berita (Suppliers) memiliki peran penting bagi kemajuan program ini berdasarkan data yang didapat oleh tim kreatif.

\section{Level Organisasi}

Struktur dan kebijakan sebuah organisasi dari sebuah media berkaitan dengan tujuan dari sebuah media.Status TVRI saat ini adalah lembaga penyiaran publik.Sebagian biaya operasional TVRI masih ditanggungoleh negara.TVRI bertugas melayani informasi untuk kepentingan publik, bersifat netral, mandiri dan tidak komersial.

TVRI merupakan stasiun televisi tertua di Indonesia. TVRI tidak berdasarkan kepemilikan pribadi atau kapitalis, tidak ada profit atau keuntungan yang di dapat karena tunduk pada Peraturan Pemerintah Nomor 13 tahun 2005. Tugas TVRI memberikan pelayanan informasi, pendidikan dan hiburan yang sehat, kontrol dan perekat sosial, serta melestarikan budaya bangsa untuk kepentingan seluruh lapisan masyarakat melalui penyelenggaraan penyiaran televisi yang menjangkau seluruh wilayah Negara Kesatuan Republik Indonesia. Namun, dengan perubahan status TVRI dari Perusahaan Jawatan ke TV Publik sesuai dengan UndangUndang Nomor 32 Tahun 2002 tentang penyiaran, direksi TVRI dapat melakukan pembenahan-pembenahan baik di bidang Manajemen, Struktur Organisasi, SDM dan Keuangan. Sehubungan dengan itu Direksi juga melakukan konsolidasi, melalui restrukturisasi, pembenahan di bidang Marketing dan Programing. TVRI akan dapat memenuhi kriteria yang disyaratkan oleh undang-undang penyiaran yaitu sebagai TV publik dengan sasaran khalayak yang jelas. 
Wulan Furrie, Program Serambi Islami Edisi Jum'at Pada Sesi Teletilawah....

\section{Level Pengaruh luar Organisasi Media}

Extra media level adalah pengaruh media yang bersumber dari luar organisasi. Pengaruh media itu berasal dari sumber berita, pengiklanan dan kontrol pemerintah, pangsa pasar dan tekhnologi. Selain sumber berita pada level pengaruh ke-2 dalam teori hirarki media ini, level pengaruh luar organisasi media juga terdapat pada share/rating TV sebagai sumber informasi yang dapat menunjukan citra Program ini.

\section{Pengaruh Ideologi}

Pada level ini kita membahas ideologi yang diartikan sebagai kerangka berfikir tertentu yang dipakai oleh individu untuk melihat realitas dan bagaimana mereka menghadapinya. Pembahasan pada level ini adalah mempelajari hubungan sebuah konten media, nilai-nilai, dan kepentingan sebuah relasi kuasa media. Pada level ideologi berbicara lebih luas mengenai bagaimana kekuatan-kekuatan yang bersifat abstrak seperti ide memengaruhi sebuah media terutama ide kelas yang berkuasa.

Sebagai media pemersatu bangsa yang berlandaskan Pancasila TVRI sudah menjadi TV publik sehingga TVRI harus bersikap netral. Pengaruh ideologi yang dimaksud dalam teori pengaruh media Shoemaker and Resee tidak tampak dalam pembuatan Program TELETILAWAH, karena tidak adanya ide kelas tertentu yang berkuasa sehingga TVRI dapat menjalankan visi dan misinya dengan baik serta tetap bisa berperan aktif dalam pembangunan di atas landasan "Persatuan dan Kesatuan" bangsa.

\section{KESIMPULAN}

1. TVRI adalah komunikator (yang menyampaikan pesan). Ada 3 komponen pesan yaitu makna, simbol untuk menyampaikan makna, dan bentuk/organisasi pesan. Makna yang disampaikan adalah bahwa TVRI yang memiliki visi ikut mencerdaskan kehidupan bangsa telah memberi kontribusi di bidang komunikasi dakwah untuk bisa membumikan Alqur'an, dengan cara mengajak pemirsa membaca Al- Qur'an secara baik dan benar (tartil) sesuai dengan kaidah yang dicontohkan oleh Rasulullah SAW. Simbol yang digunakan untuk menyampaikan makna adalah Alquran yang merupakan "The way of life" bagi umat Islam. Password yang harus disebutkan sebelum pemirsa berhasil menghubungi melalui saluran telepon TVRI dengan menyebut "cintaaaaaa...quran" Pesan yang diusung adalah bahwa Alquran sebagai pedoman hidup bagi umat Islam harus dibaca sesuai dengan tartil. Nara sumber juga menyampaikan ganjaran di dunia dan akhirat jika bisa membaca Alquran secara tartil. Diharapkan dengan pesan tersebut umat Islam mendapatkan pencerahan melalui program ini dan menemukan peningkatan dalam memahami bacaan Alquran. 
2. TVRI sebagai saluran (channel) atau media komunikasi sangat strategis untuk menyalurkan ide-ide yang mendidik dan berperan sangat besar bagi kelangsungan pendidikan di Indonesia. Mengingat televisi memiliki kekuatan untuk mengubah sikap, pendapat maupun tingkah laku individu/kelompok, maka program TELETILAWAH memiliki kekuatan tersebut untuk bisa menumbuhkan kesadaran membaca Alquran secara tartil pada pemirsa di seluruh Indonesia.

3. Bagi pemirsa Indonesia program TELETILAWAH ini bermanfaat untuk meningkatkan cara membaca Alquran dengan lebih baik, lebih mencintai dan lebih dekat dengan Alquran serta tidak lupa untuk berhadapan dengan guru Alquran (bertallaqi musafahah) yang kompeten.

4. Efek dari acara TELETILAWAH dalam program Serambi Islami adalah pemirsa makin tumbuh kesadarannya untuk membaca Quran secara tartil yang dapat mempertinggi keimanan dan meningkatkan kualitas beragama. Secara data dapat dibuktikan bahwa acara ini diminati dan ditunggu oleh pemirsa dengan atensi yang ditunjukan pemirsa yang berusaha keras untuk bisa menghubungi saluran telepon ketika program berlangsung (live).

\section{DAFTAR PUSTAKA}

Bungin, Burhan. 2008. Komunikasi, Ekonomi, Kebijakan Publik dan Ilmu Sosial Lainnya "Penelitian kualitatif"

Morrisan. 2010. Komunikasi Individu Hingga Massa" Teori komunikasi. Jakarta:

Prenada

Wahyu Ilaihi, 2008, Komunikasi Dakwah, Bandung: PT. Remaja Roda Karya

Morissan. 2008. ManajemenMedia Penyiaran Strategi Mengelola Radio dan Televisi. Jakarta: Kencana.

McQuails, Dennis. 2000. Mass Communication Theory, London: Sage Publication.

Shoemaker, Pamela J dan Stephen D. Reese. 1996. Mediating The Message, New York : Longman Publisher.

Littlejohn, Stephen W. dan Karen A. Foss. 2009. Theories of Human Communication, $9^{\text {th }}$ ed. Jakarta: Salemba Humanika.

\section{Jurnal}

Fenti Anasari dan Hamid Arifin, Pola menonton program Islam itu indah dan pemenuhuan kebutuhan spiritual (Studi Korelasi Antara Pola Menonton Program Islam Itu Indah di TRANS TV dengan Pemenuhan Kebutuhan Spiritual Mahasiswa AAI UNS), Program studi Ilmu Komunikasi Fakultas Ilmu Sosial dan Politik Universitas 11 Maret Surakarta 
Wulan Furrie, Program Serambi Islami Edisi Jum'at Pada Sesi Teletilawah....

Bondad-Brown, Rice, \& Pearce. 2012. Influences on TV Viewing and Online User-shared Video Use: Demographics, Generations, Contextual Age, Media Use, Motivations, and Audience Activity. Journal of Broadcasting \& Electronic Media.

\section{Internet}

https://islamdownload.net/125637membaca-Alquran-dengan-tartil- untuk-dapat-memaknai-ayatAlquran-secara-tepat.html

https://islamdownload.net/125384-tartilquran-di-balik-makna-membacaAlquran-secara-tartil.html

https://id.wikipedia.org/wiki/Televisi_R epublik_Indonesia

CommSci Project Gambar Model

Komunikasi Laswell

:https://www.google.co.id. 